\title{
The Effectiveness of Animal Dungs and Leaf Mold for Bioelectricity Generation Using Microbial Fuel Cell with Soils
}

\author{
Tun Ahmad Gazali, M. Azizul Moqsud* \\ Department of Civil and Environmental Engineering, Yamaguchi University, Yamaguchi, Japan \\ Email: v502wc@yamaguchi-u.ac.jp, *azizul@yamaguchi-u.ac.jp
}

\begin{abstract}
How to cite this paper: Gazali, T.A. and Moqsud, M.A. (2017) The Effectiveness of Animal Dungs and Leaf Mold for Bioelectricity Generation Using Microbial Fuel Cell with Soils. Journal of Sustainable Bioenergy Systems, 7, 165-181.

https://doi.org/10.4236/jsbs.2017.74012
\end{abstract}

Received: September 21, 2017

Accepted: November 6, 2017

Published: November 9, 2017

Copyright (๑ 2017 by authors and Scientific Research Publishing Inc. This work is licensed under the Creative Commons Attribution International License (CC BY 4.0).

http://creativecommons.org/licenses/by/4.0/

\begin{abstract}
A resource recovery from waste material is an important topic. Microbial fuel cell (MFC) is getting interest nowadays due to its superiority to generate electricity from a wide range of substrates by utilizing organic wastes. This study was aimed to investigate the potential electricity generation by utilizing animal dung and leaf mold as a very prospective substrate for bioelectricity generation using MFC. MFC as a direct current source (DC), in this experiment we focus to prove the potential difference (voltage) generated by the material. The best result is $10980 \pm 11.32 \mathrm{mV} / \mathrm{m}^{2}$ for a mixed sample of Test $\mathrm{V}$ (leaf mold and soil), while for the pure samples showed at $10880 \pm 4.784 \mathrm{mV} / \mathrm{m}^{2}$ for Test IV (chicken dropping). The advancements in this environmentally friendly study have expanded that cow dung, chicken droppings and leaf mold as a variety of organic wastes which contains large amounts of nutrients and various other minerals, as a microbial fuel cell proved to generate sustainable green and safe electricity moreover as an efficient, eco-friendly solution for organic waste management.
\end{abstract}

\section{Keywords}

Eco-Friendly Solution, Green Electricity, Microorganism, Microbial Fuel Cell, Organic Waste Management

\section{Introduction}

Our society is facing a serious energy crisis and resource recovery from organic waste. It about 1.3 billion people in the world live without access to power. Table 1 illustrates some regions in the world where still lie in no electricity. 
Table 1. Region in the world where still in no electricity.

\begin{tabular}{cccc}
\hline Region & $\begin{array}{c}\text { Population } \\
\text { (In Billion) }\end{array}$ & $\begin{array}{c}\text { Population } \\
\text { without electricity } \\
\text { (In Billion) }\end{array}$ & $\begin{array}{c}\text { \% of the lack } \\
\text { of electricity }\end{array}$ \\
\hline Asia & 3.6 & 0.622 & 17.2 \\
Africa & 1.1 & 0.6226 & 56.6 \\
Middle east & 0.2148 & 0.0177 & 8.2 \\
Latin America & 0.4661 & 0.0232 & 4.9 \\
Around the world & 7.5 & 1.3 & 17.3 \\
\hline
\end{tabular}

Source: reprocessed from https://www.washingtonpost.com/graphics/world/world-without-power/

Search of alternative energy such as organic waste resource recovery is an important topic. The organic waste which generated has increased rapidly over the last few decades and a major portion of the total solid waste in developing countries is organic waste, and it is not properly treated for resource recovery such as investigated by Sujauddin, Huda and Hoque (2008) [1] that solid waste management (SWM) is a multidimensional challenge faced by urban authorities, especially in developing countries, while Moqsud, M.A. (2003) [2] and Zurbrugg et al., (2005) [3] studied the organic waste can be effectively recycled by composting. If about $15 \%$ of the waste is abandoned in the environment without any treatment or it is not properly treated for resource recovery, they entail unique problems as shown in Table 2.

Whereas, the organic wastes contain large amounts of nutrients and various other minerals. Cristiani et al.(2013) [4] considered the advancements in environmentally friendly technologies have expanded the variety of organic wastes and renewable biomass types that could act as potential substrates to produce electrical energy or other high-value added products. Table 3 shows the nutritional values of organic wastes and soil used in this research.

Mostafa et al. (2011) [5] considered one of the renewable energy sources to produce electricity is fuel cells (FC). Moqsud, Omine and Yasufuku (2012) [6] and Moqsud et al. (2013) [7] investigated some previous studied for MFC use the available substrates from renewable sources and convert them into harmless by-products with the simultaneous production of electricity. Allen and Bennetto (1993) [8], Daniel et al. (2009) [9] and Li et al. (2012) [10] evaluated for electricity generation using waste water. Bennetto (1984) [11] and Logan et al. (2006) [12], Logan et al. (2007) [13] studied using bacteria. Habermann and Pommer (1991) [14] were to develop a low maintenance fuel cell system with long-term stability with sulphide storage capacity. Hong et al. (2009) [15] developed microbial fuel cell using sediment. Khalid et al. (2011) [16] developed organic waste for biogas and other energy-rich compounds. Microbial fuel cell using sewage sludge as fuel was studied by Jiang et al. (2010) [17]. Spiegel and Preston (2003) demonstrated energy from anaerobic digester gas (ADG). Zang et al. (2009) [19] analyzed microbial communities in wheat straw biomass-powered microbial 
Table 2. Environmental problems due to livestock farming in Japan (2010).

\begin{tabular}{cccccc}
\hline & Stink & Water pollution & Pest & Others & Total \\
\hline Dairycattle & 390 & 199 & 24 & 151 & 685 \\
Beef cattle & 220 & 114 & 22 & 70 & 394 \\
Hog & 466 & 246 & 8 & 50 & 663 \\
Poultry & 254 & 44 & 87 & 33 & 399 \\
Others & 27 & 11 & 4 & 7 & 44 \\
Total & 1,357 & 614 & 145 & 311 & 2185 \\
Percentage & 62.1 & 28.1 & 6.6 & 14.2 & 100.0 \\
\hline
\end{tabular}

Source: MAFF, Department of Production (2010). Notes: 1) The number of problems indicates the number of local residents' complaints on environmental problems to local government in the given year, 2) The percentage is the rate of livestock farmers in trouble out of the total number of livestock farmers; 3 ) "Others" includes noise and inflow of animal waste.

Table 3. Nutritional values of organic waste and soil.

\begin{tabular}{ccccc}
\hline Parameter & Soil & Cow dung & Chicken dropping & Leaf mold \\
\hline $\mathrm{N}(\mathrm{mg} / \mathrm{kg})$ & 5.1 & 2.04 & 1.72 & 4.3 \\
$\mathrm{P}(\mathrm{mg} / \mathrm{kg})$ & 10.3 & 0.76 & 1.82 & 3.6 \\
$\mathrm{~K}(\mathrm{mg} / \mathrm{kg})$ & 124.2 & 0.82 & 2.18 & 5.0 \\
$\mathrm{EC}(\mathrm{mS} / \mathrm{cm})$ & 0.395 & 18.7 & 19.74 & 1.5 \\
$\mathrm{C} / \mathrm{N}$ ratio & 6.72 & 19.9 & 9.65 & 10.2 \\
\hline
\end{tabular}

fuel cells. Moqsud, M.A. and Omine, K. (2010) [20] investigated bioelectricity generation by using paddy plant microbial fuel cells (PMFCs) in soil mixed with compost. Wang et al. (2009) [21] studied by corn stover biomass while Hassan et al. (2014) [22] evaluated rice straw for electricity. Velasquez-Orta, Curtis and Logan (2009) [23] investigated algae in microbial fuel cells. Jauharah, Boris and Raghavan (2015) [24] developed electricity from a mix of fruit and vegetable wastes. Brahmaiah, P. et al. (2016) [25] investigated municipal solid waste generated electricity. Resch, Hass and Faber (2008) [26] considered the production of electricity or biofuels using innovative technologies and renewable sources is a global priority in terms of energy strategies.

This research becomes very important and very interesting because of the increasing need for alternative energy while the amount of non-renewable fuel is decreasing. MFC has been well established for almost one hundred years. However, Jessica Li (2013) [27] investigated this capability did not exceed laboratory-based experiment until the 20th century when research on this subject and the creation of MFCs received sporadic approach. The objective of this study is to focus on and prove the ability of some cheap and abundant-organic wastes such as cow dung, chicken dropping and leaf mold mixed with soil as a very prospective substrate for bioelectricity generation. Thus, it develops a microbial fuel cell that generates green and safe electricity using animal dungs and leaf mold mixing with soil as an efficient, renewable and an eco-friendly solution for organic waste management. 


\section{Materials and Methods}

\subsection{Experimental Materials and Laboratory Instruments}

To conduct the experiments which was done in Department of Civil and Environmental Engineering of Yamaguchi University-Japan, some materials were prepared such as carbon felt, soil, cow dung, chicken droppings, leaf mold, effective microorganisms/EM (commercially available from EM Kenkyusho, Shizuoka, Japan), acrylic rectangular chambers, volt meter, resistors, iron wires, alligator clips, capacitor and some supporting test equipment.

The EM which used in this work was for each case to start the bioelectricity generation and to reduce possible odour from organic wastes during the investigation. The Soil which used in whole experiments were sampled in the $10 \mathrm{~cm}$ layer of natural Tokiwa Park soil, located in the plant area of Tokiwa Park $\left(33^{\circ} 57^{\prime} 02.9^{\prime \prime} \mathrm{N}, 131^{\circ} 16^{\prime} 47.5^{\prime \prime} \mathrm{E}\right)$ at Ube city, Yamaguchi Prefecture, Japan. The soil used in this work as they are thought to increase not only the physical volume of samples properties and the optimum content but it also to increase the nutrient ability supplying food for microorganism to generate electricity. A $16 \mathrm{~V} 1000 \mu \mathrm{F}$ capacitor was used in this research to store the electric energy, to reduce the voltage with less power wasted and to keep constant voltage. Carbon felt type of Kreca Felt X F 210-X was used. Some advantages that arise in using of carbon felt such as a large surface area that offers sufficient reaction sites for the electron-transfer re-actions, their suitability for mass production and good process ability, but their properties vary with the raw material used for their fabrication. The property of the electrodes shows at Table 4. Furthermore, Figure 1 show the SEM images of carbon felt as electrodes. The cow dung were taken from the Department of Agriculture, Yamaguchi University at Yoshida campus, Japan. The chicken droppings and leaf mold were collected from Japan Agricultural Office, Ube city branch.

\subsection{MFC Assembly}

In this study the MFCs employed a blend of some organic wastes and soil which over a testing time within 21 days. Figure 2 describes the schematic diagram for the MFC in this study. Then, an amount of each organic waste (400 g), $400 \mathrm{~g}$ of soil and add $4 \mathrm{~g}$ of EM were blended with added $150 \mathrm{ml}$ of water until mixed completely.

Table 4. Properties of carbon felt.

\begin{tabular}{cc}
\hline Properties & Measure value \\
\hline Fiber grade & Carbonized \\
Ash content $(\%)$ & $\leq 1.0$ \\
Thickness $(\mathrm{mm})$ & 10 \\
Unit mass $\left(\mathrm{g} / \mathrm{m}^{2}\right)$ & 500 \\
Bulk density $\left(\mathrm{kg} / \mathrm{m}^{3}\right)$ & 50 \\
Carbon content $(\%)$ & $\geq 97$ \\
\hline
\end{tabular}



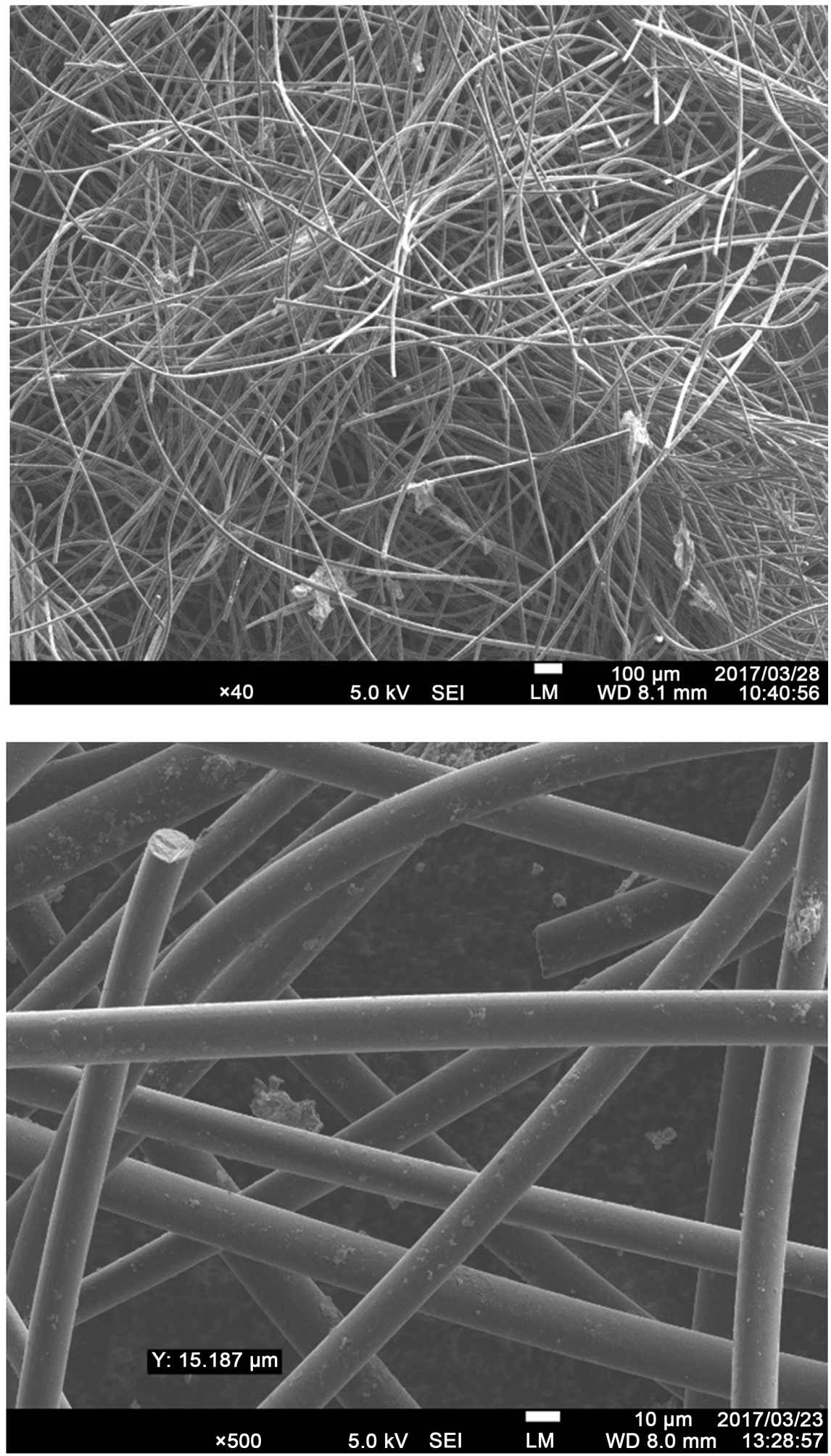

Figure 1. SEM image of carbon felt as electrode.

The blended sample was poured into the container. Carbon felt was used for both electrodes (anode and cathode).The anode was set approximately $5 \mathrm{~cm}$ below the surface of the compost, while the cathode was placed immediately above 


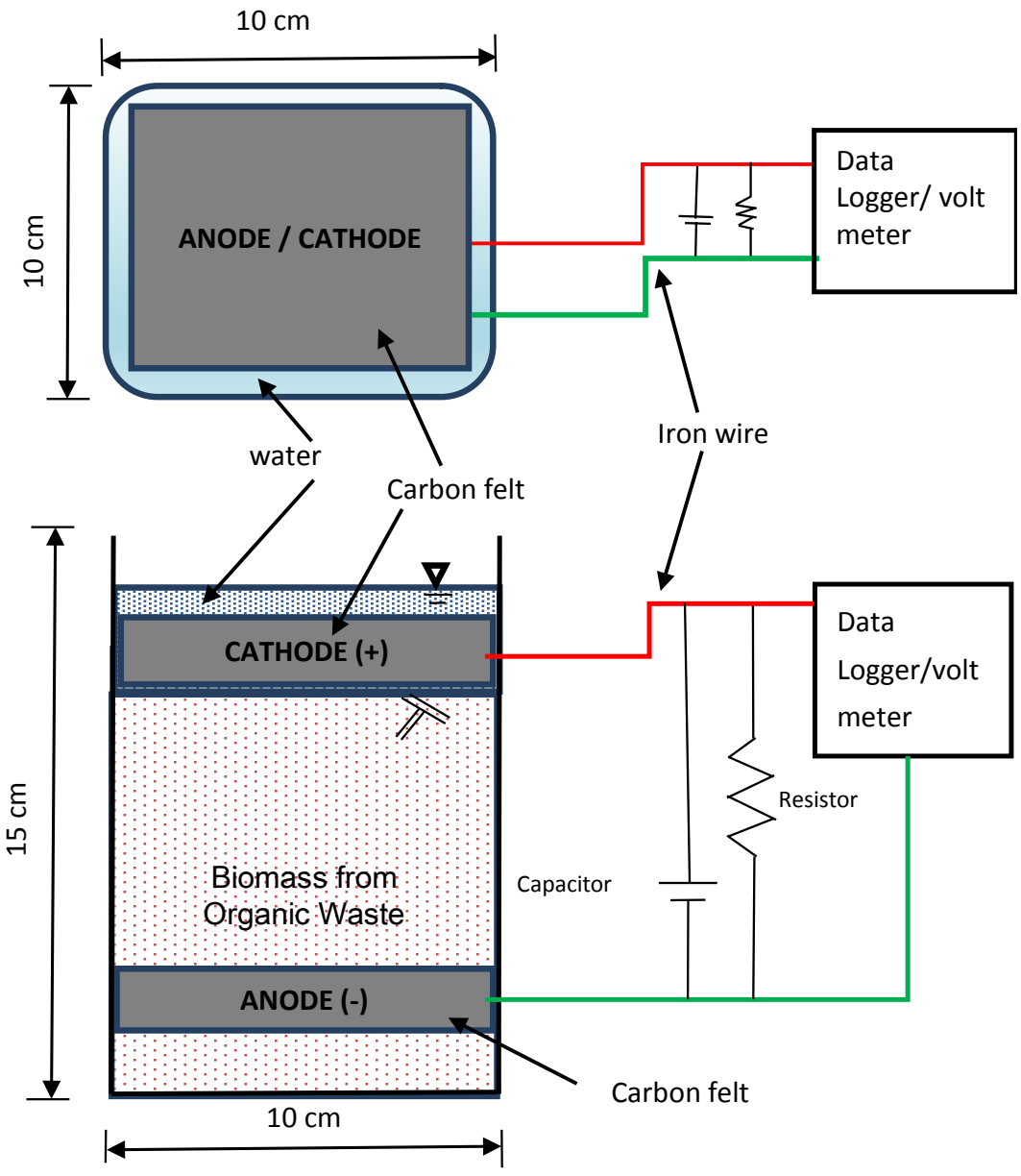

Figure 2. The schematic diagram of the microbial fuel cell used in this study.

the compost surface, but under the water. The area of electrodes was kept the same as the cell areas $\left(100 \mathrm{~cm}^{2}\right)$. Both the anode and cathode were connected by a single iron wires and had a fixed external capacitor and a resistance (100 $\Omega$ ) used as the load for the power being generated which measured by volt meter daily. The laboratory tests were conducted under a constant room temperature of $25^{\circ} \mathrm{C}$. Experiments were conducted with pure samples and mixed samples.

In the anode compartment of MFC devices, microorganisms metabolize a substrate such as sugar in absence of oxygen, and they produce carbon dioxide, protons and electrons as describe below:

$$
\mathrm{C}_{12} \mathrm{H}_{22} \mathrm{O}_{11}+13 \mathrm{H}_{2} \mathrm{O} \rightarrow 12 \mathrm{CO}_{2}+48 \mathrm{H}^{+}+48 \mathrm{e}^{-}
$$

When oxygen is supplied from air to the cathode, following reaction is proposed:

$$
6 \mathrm{O}_{2}+24 \mathrm{H}^{+}+24 \mathrm{e}^{-} \rightarrow 12 \mathrm{H}_{2} \mathrm{O}
$$

\subsection{Loss on Ignition Test (LOI) of the Samples}

Since the publication of the paper of Dean (1974), loss on ignition (LOI) has been widely used as a method to estimate the amount of organic matter. 
Walter, E. and Dean, J.R. (1974) [28] evaluated LOI test is a common and widely used method to examine the organic compounds. We conducted LOI test of the four samples used in this research. The content of organic matter is to have greatly influence to the amount of power generation in this microbial fuel cell. Table 5 shows the LOI test results of the four samples. The sample which contains the most organic matter of $87.24 \%$ is cow dung. The lowest value of $20.33 \%$ is for soil. It is considered that more organic substances in a mixture of organic waste with soil that can influence on more voltage generation than soil only.

\subsection{Experiments on Pure Samples}

4 samples of $400 \mathrm{~g}$ of cow dung, chicken droppings, leaf mold, and soil were prepared and investigated separately. Then they were added in to the each acrylic rectangular after blended completely. All samples parameter condition was showed by Table 6 as described below.

\subsection{Experiments on Mixed Samples}

Soil and organic wastes in this work were mixed with a ratio of the same volume to generate bioelectricity in a microbial fuel cell (MFC). Quanguo, Jianjun and $\mathrm{Du}$ (2016) [29] investigated MFC as a device that can convert chemical energy in influent substances to electricity via biological pathways. As there are many microorganisms in the soil. Fedorovich et al. (2009) [30] and Juang et al. (2011) [31] studied the bacterial communities in MFC known exoelectrogenic bacteria in an acetate-fed MFC. In microbial fuel cells (MFCs), many microorganisms work in a consortium state, meaning they are not in the same pure colony, but

Table 5. Result of the loss on ignition tests.

\begin{tabular}{cc}
\hline Sample name & Loss on ignition (LOI) \\
\hline Soil & $20.33 \%$ \\
Cow dung & $87.24 \%$ \\
Chicken dropping & $82.55 \%$ \\
Leaf mold & $80.33 \%$ \\
\hline
\end{tabular}

Table 6. Parameter conditions for pure samples.

\begin{tabular}{ccccc}
\hline Parameter & $\begin{array}{c}\text { Test I } \\
\text { (Soil) }\end{array}$ & $\begin{array}{c}\text { Test II } \\
\text { (leaf mold) }\end{array}$ & $\begin{array}{c}\text { Test III } \\
\text { (Cow dung) }\end{array}$ & $\begin{array}{c}\text { Test IV } \\
\text { (Chicken droppings ) }\end{array}$ \\
\hline Soil (g) & 400 & 0 & 0 & 0 \\
Organic waste (g) & 0 & 400 & 400 & 400 \\
pH & 6.32 & 5.48 & 6.72 & 6.22 \\
Electrodes (carbon felt) & Yes & Yes & Yes & Yes \\
EM (g) & 4 & 4 & 4 & 4 \\
Water (ml) & 150 & 150 & 150 & 150 \\
\hline
\end{tabular}


many of them and some of which have been identified as Geobacter metallireducens, and Rhodoferrax ferrireducens. While Geobacter metallireducens is a class of bacteria from the genus geobacter unique because it can produce like filaments that act as nanowires to transfer electrons from outside the cell to the insoluble electron acceptor such as iron minerals and most likely to electrodes. It is considered that more voltages can be obtained by mixing soil with organic matter. Moreover, the blended soil and some of organic waste in this work as they are thought to increase the physical volume of samples properties and it increases the nutrient supply ability for microorganism. The type and number of microorganisms which survive are different by region in the distribution of the soil. The mixture of organic constituents in the waste and microorganisms in the soil are expected to lead the higher values of output voltage. Table 7 illustrates the parameter condition for mixed samples.

\subsection{Measurement}

Since MFC is the source of direct current (DC), in this experiment we calculate the magnitude of the potential difference (voltage) between the anode and cathode poles. The voltage which generated across the resistor and capacitor was monitored every day at $1 \mathrm{pm}$. It is estimated that at that time is the most appropriate time for research measurement. In this research, we present the MFC's electric potentials in volts per square meter because of the difference in electrical potential between the two electrodes in the MFC circuit as the main-focus and related to the advanced plan of this research that we want to know the potential of electricity generated when coupled series due to differences potential resulting by each MFC reactor. Polarization curve and power density-current curves were investigated as described by Logan and Regan (2006) [32] who formulated polarization curve and power density-current curves by using different resistors and internal resistances and power densities. Electrode output was measured in volts $(\mathrm{V})$ against time. The current $I$ in amperes (A) was calculated using Ohm's law,

$$
I=V / R
$$

where $V$ is the measured voltage in volts $(V)$ and $R$ is the known value of the external load resistor in Ohms (100 $\Omega$ in this study). From this, it is possible to

Table 7. Parameter condition for mixed samples.

\begin{tabular}{cccc}
\hline Parameter & $\begin{array}{c}\text { Test V } \\
\text { (Leaf mold + soil) }\end{array}$ & $\begin{array}{c}\text { Test VI } \\
\text { (Cow dung + soil) }\end{array}$ & $\begin{array}{c}\text { Mixed test VII } \\
\text { (Chicken droppings + soil) }\end{array}$ \\
\hline Soil (g) & 400 & 400 & 400 \\
Organic waste (g) & 400 & 400 & 400 \\
pH & 6.83 & 6.48 & 7.2 \\
Electrodes (carbon felt) & Yes & Yes & Yes \\
EM (g) & 4 & 4 & 4 \\
Water (ml) & 150 & 150 & 150
\end{tabular}


calculate the power output $P$ in watts (W) of the MFCs by taking the product of the voltage and current i.e.

$$
P=I \times V
$$

The power density and current density was calculated using:

$$
\begin{aligned}
& \text { Power density }=(I \times V) / \alpha \\
& \text { Current density }=(V / R) / \alpha
\end{aligned}
$$

where $\alpha$ is the electrode area. Normally, the anode area is taken as the electrode area. For example, if the electrode material is rectangular the area will be simply the length multiplied by width.

Furthermore, the root-mean-square deviation (RMSD) is used as a statistical analysis which is a good accuracy measurement. It serves to aggregate the magnitudes of various errors into a single measure. The RMSD is used to compare differences that may vary, neither of which is accepted as the result within the total period of the experiment.

\section{Results and Discussion}

\subsection{Bioelectricity Results in MFC}

Figure 3 provides the variation of voltage with duration in microbial fuel cell using pure samples. The maximum value of electricity production were $10880 \pm$ $4.784 \mathrm{mV} / \mathrm{m}^{2}, 8980 \pm 3.265 \mathrm{mV} / \mathrm{m}^{2}, 6280 \pm 5.887 \mathrm{mV} / \mathrm{m}^{2}, 6070 \pm 7.048 \mathrm{mV} / \mathrm{m}^{2}$ for pure samples of Test IV, Test II, Test III, and Test I, respectively.

It is described that for the pure samples, until 21 days of monitoring an increasing-decreasing trend in between each 2 - 9 and $11-17$ days of output voltage were observed in the MFCs, and most of increasing trend among 2 - 9 days in all the MFCs. However, among 2 - 5 days as initial stage were obtained the

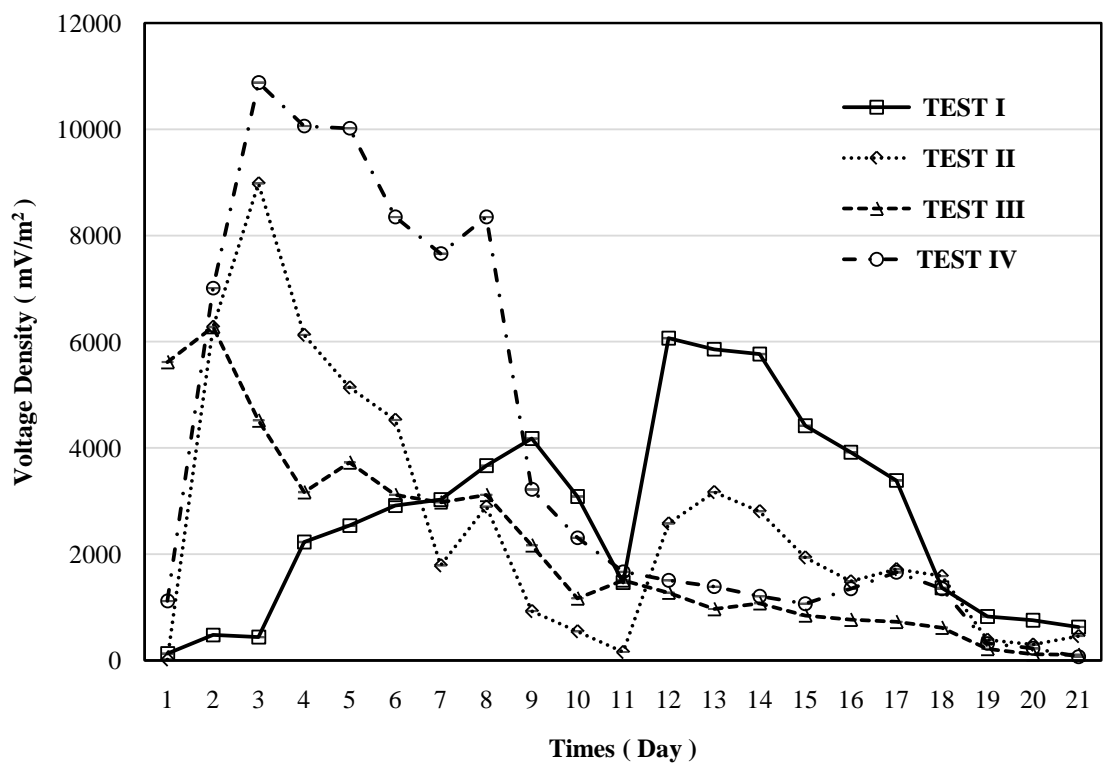

Figure 3. Variation of voltage with duration in microbial fuel cell using pure samples. 
highest peaks of voltages in all experiments, then the electricity production of a MFC gradually decreases over period of 15 days. Moqsud, Bushra and Rahman (2011) [33] investigated during the initial stage since the bacteria got ample food and their activities increased very rapidly and because the samples were used several hours after collection, the bacterial colony might have already grown exponentially. The bacteria naturally produce electricity through their ability to degrade organic compounds in the sample. The growth of microorganisms in general depends on the condition of foodstuffs and the environment. If food and environmental conditions are suitable for these microorganisms, then microorganisms will grow with a relatively short time and perfect. For that reason, the voltage increased sharply. Afterwards by the time the samples were used to power the MFC, the bacteria might have already begun depleting their resources and the supply of food was used up by the bacteria as Moqsud et al. (2014) [34] stated in their study, then the electricity production decreased steadily over the period of 15 days.

\subsection{Experimental Results from Mixed Samples}

The comparison for changes in voltage among triplicate models of mixed samples is shown by Figure 4. In this case, it shows the result of mixed samples within 3 days of initial time, the bacteria got ample food and their activities increased very rapidly, the voltage (V) increased sharply. Afterwards, after 12 days the voltage decreasing trend gradually with time was observed as the sample still had high percentage of organic matter as supply of food for the bacteria. The maximum value of voltage was $10980 \pm 11.32 \mathrm{mV} / \mathrm{m}^{2}, 10530 \pm 4.921 \mathrm{mV} / \mathrm{m}^{2}$ and $4440 \pm 9.741 \mathrm{mV} / \mathrm{m}^{2}$ for a mixed sample of Test V, Test VII, and Test VI, respectively.

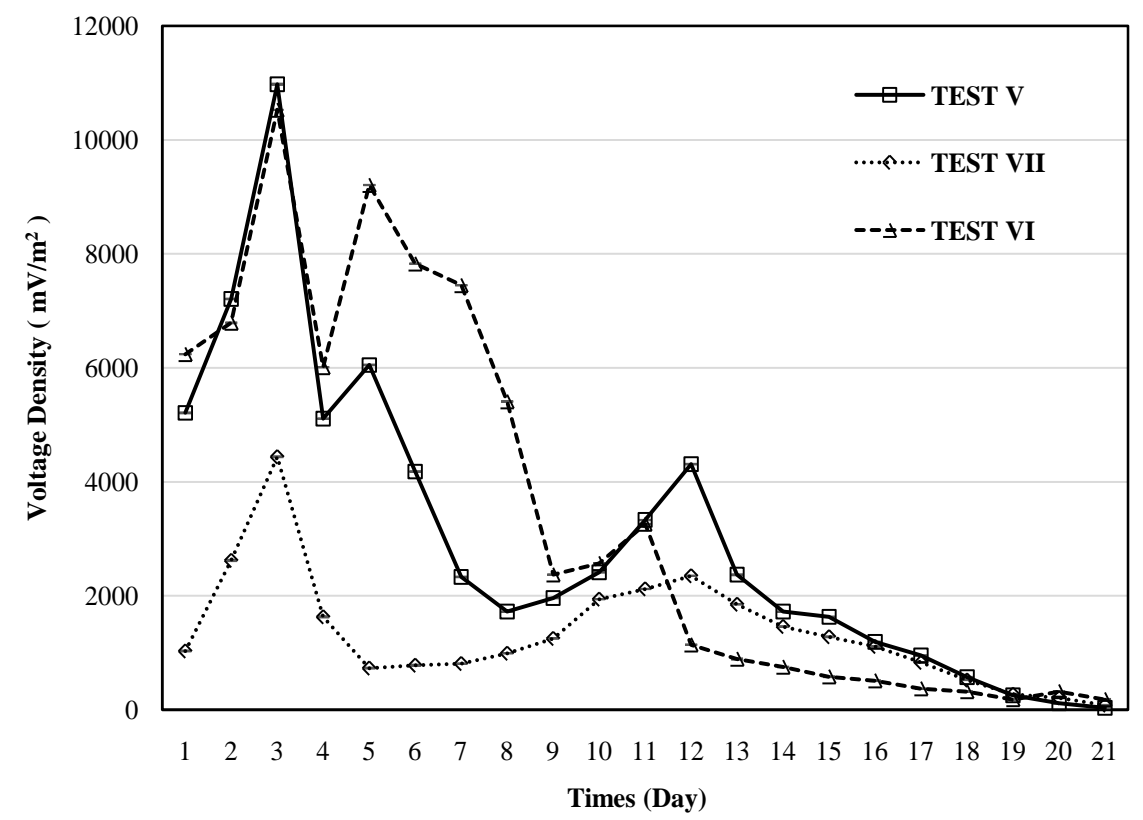

Figure 4. Variation of voltage with time obtained by mixed samples. 
A reason why the mixed sample of Test $\mathrm{V}$ showed a higher value of voltage than the other samples is that leaf mold, as a form of compost, as Jati S.H. (2001) [35] and Hamzah (1983) [36] investigated compost is rich in nutrients and organic matter which supports the growth of microorganisms.

\subsection{Polarization Curve for MFCs}

The polarization curves of the MFC using mixed sample are illustrated in Figure 5. A polarization curve is used to characterize current as a function of voltage. They show how well the MFC maintains voltage as a function of the current production. The trend of the polarization curve was very much similar with the polarization curves which have been found in other literature concerning MFCs as studied by Logan and Regan (2006) [32].

It shows that the maximum power density of $79.885 \pm 1.7 \mathrm{~mW} / \mathrm{m}^{2}$ for Test $\mathrm{V}$ and $71.76 \pm 1.11 \mathrm{~mW} / \mathrm{m}^{2}$ for Test VI. The power densities showed an incremental trend with decreasing external resistance and reaches a peak value. After that, the power densities began to fall with increasing current density, which indicated typical fuel cell behavior.

\subsection{Relationship between Voltage and Current in the MFCs}

Figure 6 shows the relationship between voltage and current in the MFCs for $3^{\text {rd }}$ day of elapsed time. It is found that the relationship was almost linear. The intercept and inclination of the line represents electromotive force and internal resistance for the MFCs, respectively. It represents that MFC with a good per-

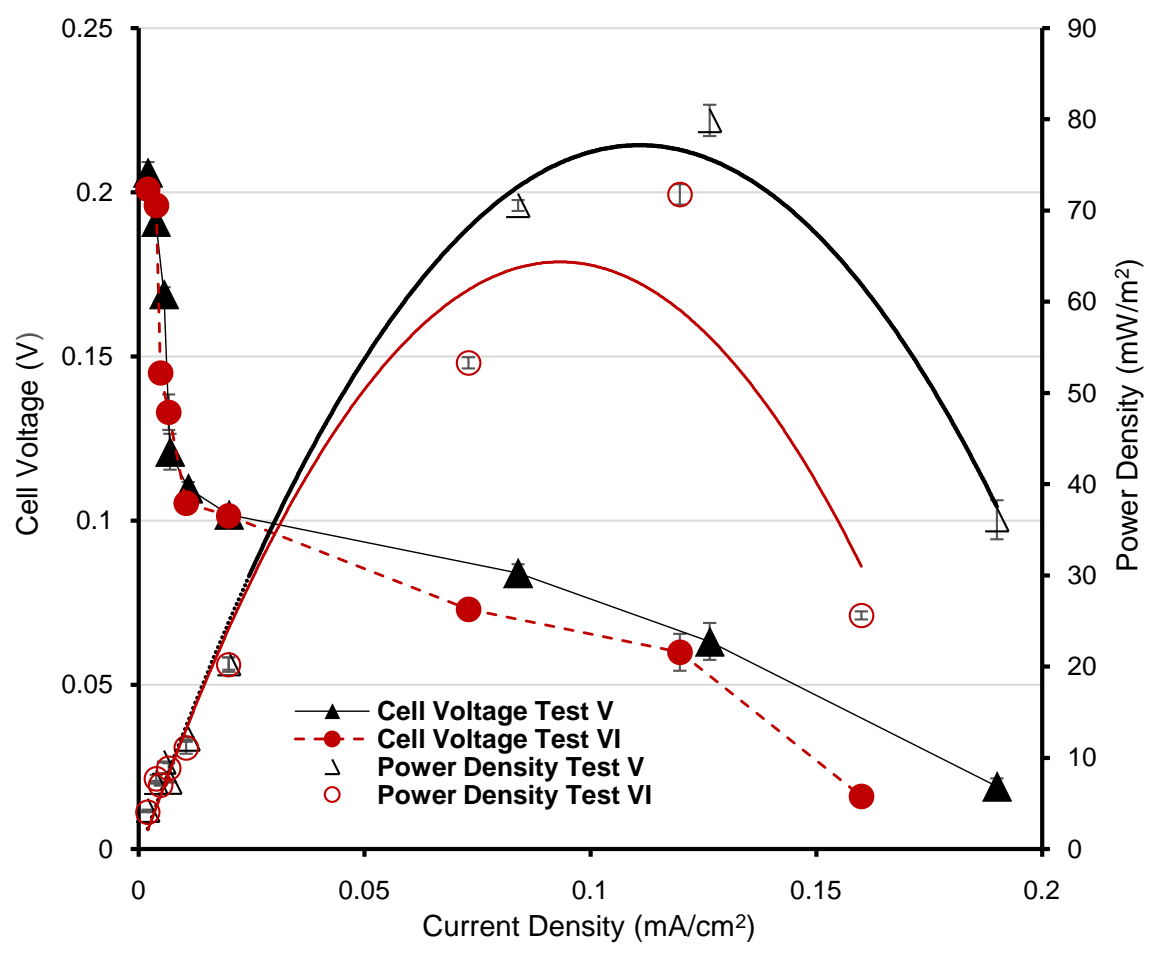

Figure 5. Polarization curve of the MFC. 


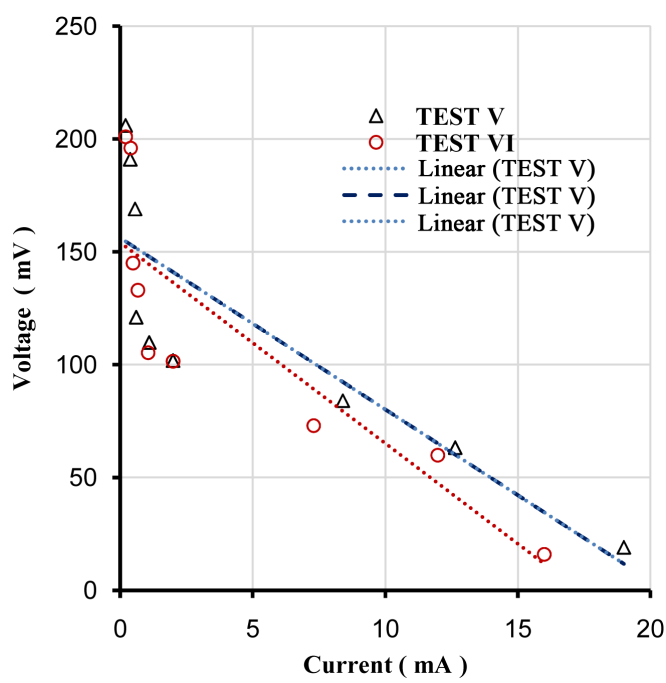

Figure 6. Relationship between voltage and current in the MFCs at $3^{\text {rd }}$ day.

formance indicates high electromotive force and low internal resistance. The electromotive force of MFC of Test V was $206 \pm 0.33 \mathrm{mV}$. On the other hand, the electromotive force of Test VI was $201 \pm 0.53 \mathrm{mV}$. The maximum power density for Test $\mathrm{V}$ was $79.885 \pm 1.7 \mathrm{~mW} / \mathrm{m}^{2}$ and $71.76 \pm 1.11 \mathrm{~mW} / \mathrm{m}^{2}$ for Test VI. The consideration of this result, as described above, since leaf mold in Test $\mathrm{V}$ is rich in nutrients and organic matter which supports the growth of microorganisms. The test results obtained from Figure 6 are given in Table 8. Maximum electric power is calculated from the linear relationship between voltage and current.

\subsection{Carbon Felt as Electrode Materials}

After the tests, to examine the performance of organic waste, anode and cathode, they were removed from the fuel cells and were checked by electronic microscopes. It was observed that on most parts of the anode or cathode, there were parts of organic waste that was still firmly bonded to the carbon felt. These findings indicate that the good bonding for each sample might have acted as bonding agent for the electron. The bonding area and number of bonding area of the organic wastes and the electrodes shows that they can catch and discharge the electrons and more number of them show that more electron can catches by or discharge by them. So, the organic waste can work optimally with carbon felt as the electrode materials, as results shown in Figure 7(a) which shows the SEM images of organic waste as compost and Figure $7(\mathrm{~b})$ shows of good bonding between organic waste and electrode.

The energy dispersive spectroscopy (EDS) spectrum is presented in Figure 8. Energy dispersive spectroscopy was employed to identify the presence of element of carbon felt and persimmon waste. The EDS spectra Figure 4 show the presence of $86.25 \%$ carbon, $10.52 \%$ oxygen, $0.37 \%$ sodium, $1.16 \%$ aluminium and $1.69 \%$ silicon. The appearance of aluminium and silicon on EDS is due to the use of silicon as a sample coating and aluminium as a sample plate. 

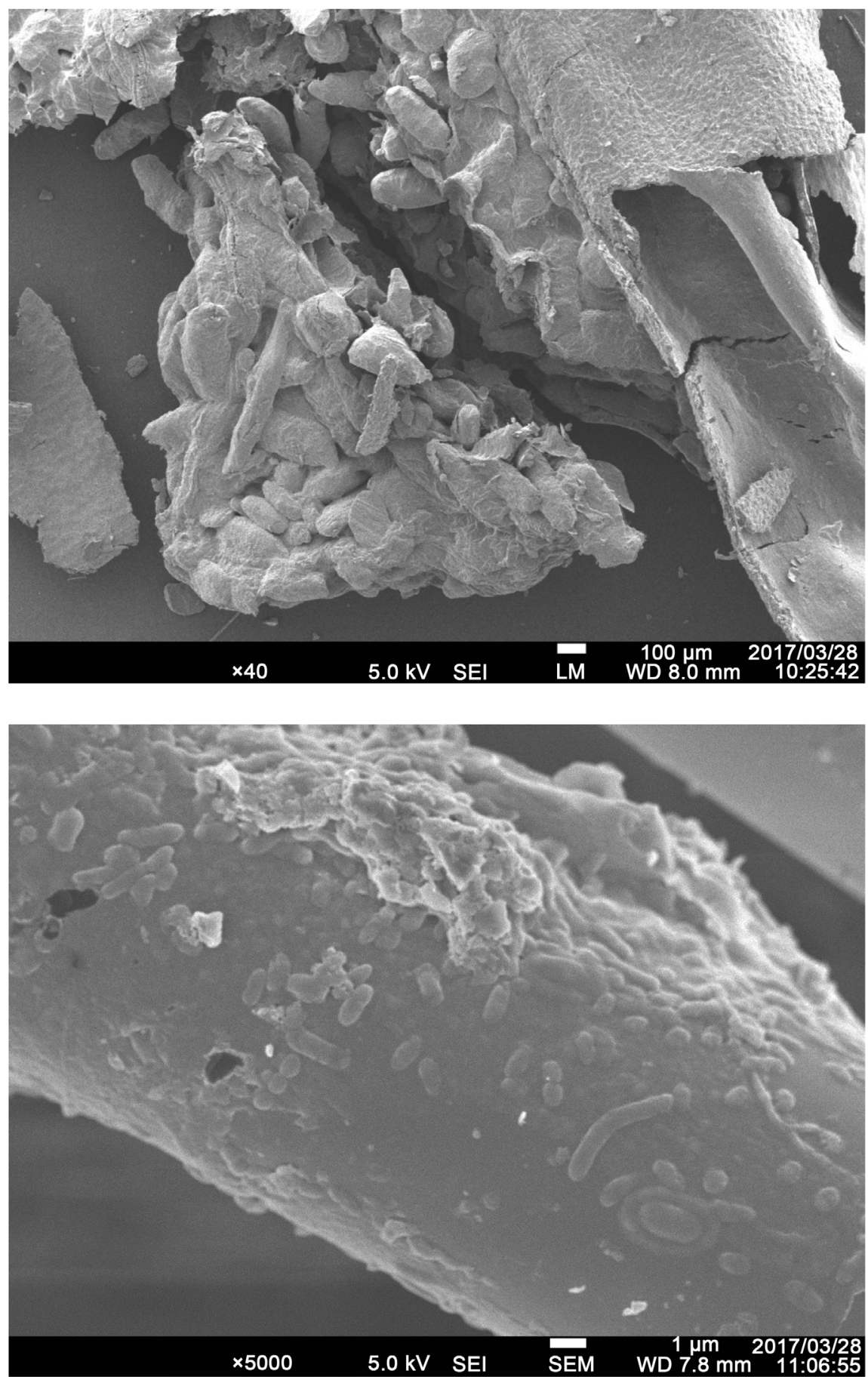

Figure 7. (a) Images of organic waste and electrode by SEM; (b) SEM image of good bonding between organic waste and electrode.

Table 8. Test results of MFCs in case of test V and test VI.

\begin{tabular}{ccc}
\hline & Test $\mathrm{V}$ & Test VI \\
\hline Electromotive force $(\mathrm{mV})$ & $206 \pm 0.33$ & $201 \pm 0.53$ \\
Internal resistance $(\Omega)$ & 1000 & 1000 \\
Maximum power per area of cathode $\left(\mathrm{mW} / \mathrm{m}^{2}\right)$ & $79.885 \pm 1.7$ & $71.76 \pm 1.11$ \\
\hline
\end{tabular}




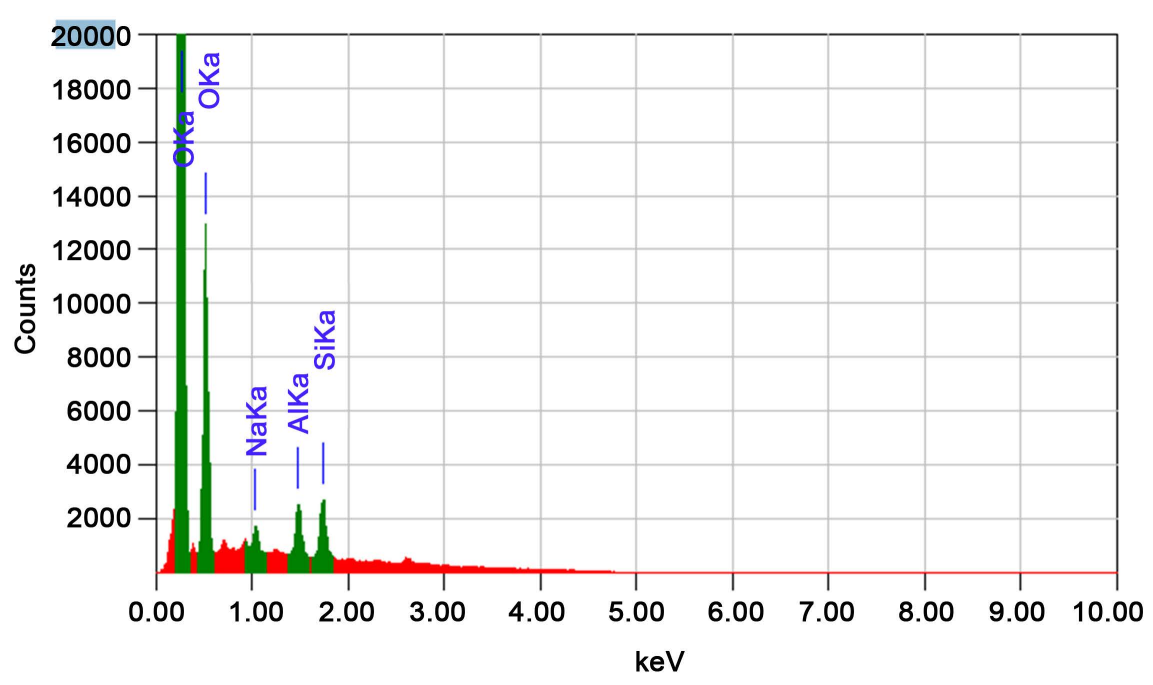

Figure 8. EDS spectrum of electrode sample.

\section{Conclusions}

1) MFC is the source of direct current (DC). In this experiment, we calculate the magnitude of the potential difference (voltage) between the anode and cathode poles. The maximum voltage density is $10880 \pm 4.784 \mathrm{mV} / \mathrm{m}^{2}$ for pure samples of Test IV (chicken dropping) and $10980 \pm 11.32 \mathrm{mV} / \mathrm{m}^{2}$ for mixed sample of Test V (leaf mold and soil). It is considered that the mixture of organic waste, soil and carbon felt as an electrode greatly supports the growth of microorganisms in working optimally to generate bioelectricity.

2) It proved that animal dungs and leaf mold as a variety of organic wastes contains large amounts of nutrients and various other minerals. It can improve to be more valuable as a microbial fuel cell to generate green and safe electricity, moreover, as an efficient, eco-friendly solution for organic waste management. This is a useful method of green and safe energy. Therefore, bioelectricity can be produced using mixed samples of organic waste and soil.

\section{Conflict of Interest}

The authors declare that the research was conducted in the absence of any commercial or financial relationships that could be construed as a potential conflict of interest.

\section{References}

[1] Sujauddin, M., Huda, S.M. and Hoque, A.T. (2008) Household Solid Waste Characteristics and Management in Chittagong, Bangladesh. Waste Management, 28, 1688-1695. https://doi.org/10.1016/j.wasman.2007.06.013

[2] Moqsud, M.A. (2003) A Study on Composting of Solid Waste in Bangladesh. Master's Thesis, Bangladesh University of Engineering and Technology, Bangladesh.

[3] Zurbrugg, C., Drescher, S., Rytz. I., Sinha, A.M.M. and Enayettullah, I. (2005) Decentralized Composting in Bangladesh, a Win-Win Situation for All Stakeholders. Resources, Conservation and Recycling, 43, 281-292. 
https://doi.org/10.1016/j.resconrec.2004.06.005

[4] Cristiani, P., Franzetti, A., Gandolfi, I., Guerrini, E. and Bestetti, G. (2013) Bacterial DGGE Fingerprints of Biofilms on Electrodes of Membraneless Microbial Fuel Cells. International Biodeterioration \& Biodegradation, 84, 211-219. https://doi.org/10.1016/j.ibiod.2012.05.040

[5] Mostafa, R., Ali, A., Ghoreyshi, Ghasem, N. and Tahereh, J. (2011) Power Generation from Organic Substrate in Batch and Continuous Flow Microbial Fuel Cell Operations. Applied Energy, 88, 3999-4004.

https://doi.org/10.1016/j.apenergy.2011.04.017

[6] Moqsud, M.A., Omine, K. and Yasufuku, N. (2012) A Comparison Study of Bioelectricity Generation by Using Kitchen Garbage and Bamboo Waste in Microbial Fuel Cell. Proceedings of the 27 th International Conference on Solid Waste Technology and Management, Philadelphia, PA, 11-14 March 2012, 1052-1061.

[7] Moqsud, M.A., Omine, K., Yasufuku, N., Hyodo, M. and Nakata, Y., (2013) Microbial Fuel Cell (MFC) for Bioelectricity Generation from Organic Wastes. Waste Management, 33, 2465-2469. https://doi.org/10.1016/j.wasman.2013.07.026

[8] Allen, R.M. and Bennetto, H.P. (1993) Microbial Fuel Cells. Electricity Production from Carbo Hydrates. Applied Biochemistry and Biotechnology, 39, 27-40. https://doi.org/10.1007/BF02918975

[9] Daniel, D.K., Mankidy, B.D., Ambarish, K., Manogari, R. (2009) Construction and Operation of a Microbial Fuel Cell for Electricity Generation from Waste Water. International Journal of Hydrogen Energy, 34, 7555-7560. https://doi.org/10.1016/j.ijhydene.2009.06.012

[10] Li, X., Zhu, N., Wang, Y., Li, P., Wu, P. and Wu, J. (2012) Animal Carcass Wastewater Treatment and Bioelectricity Generation in Up-Flow Tubular Microbial Fuel Cells: Effects of HRT and Non-Precious Metallic Catalyst. Bioresource Technology, 128, 454-460. https://doi.org/10.1016/j.biortech.2012.10.053

[11] Bennetto, H.P. (1984) Microbial Fuel Cells, Life Chemistry Reports. Harwood Academic, London, 363-453.

[12] Logan, B.E., Hamelers, B., Rozendal, R., Schroder, U., Keller, J., Freguia, S., Aelterman, P., Verstraete, W. and Rabaey, K. (2006) Microbial Fuel Cells: Methodology and Technology. Environmental Science and Technology, 40, 5181-5192. https://doi.org/10.1021/es0605016

[13] Logan, B., Cheng, S., Watson, V. and Estadt, G. (2007) Graphite Fiber Brush Anodes for In-Creased Power Production in Air-Cathode Microbial Fuel Cells. Environmental Science \& Technology, 41, 3341-3346. https://doi.org/10.1021/es062644y

[14] Habermann, W. and Pommer, E.H. (1991) Biological Fuel Cells with Sulphide Storage Capacity. Applied Microbiology and Biotechnology, 35, 128-133. https://doi.org/10.1007/BF00180650

[15] Hong, S.W., Chang, I., Choi, Y. and Chung, T. (2009) Experimental Evaluation of Influential Factors for Electricity Harvesting from Sediment using Microbial Fuel Cell. Bioresource Technology, 100, 3029-3035.

[16] Khalid, A., Arshad, M., Anjum, M., Mahmood, T. and Dawson, L. (2011) The Anaerobic Digestion of Solid Waste. Waste Management, 31, 1737-1744.

[17] Jiang, J., Zhao, Q., Wei, L. and Wang, K. (2010) Extracellular Biological Organic Matters in Microbial Fuel Cell using Sewage Sludge as Fuel. Water Research, 44, 2163-2170. 
[18] Spiegel, R.J. and Preston, J.L. (2003) Technical Assessment of Fuel Cell Operation on Anaerobic Digester Gas at the Yonkers, NY, Wastewater Treatment Plant. Waste Management, 23, 709-717.

[19] Zhang, Y., Min, B., Huang, L. and Angelidaki, I. (2009) Generation of Electricity and Analysis of Microbial Communities in Wheat Straw Biomass-Powered Microbial Fuel Cells. Applied and Environmental Microbiology, 75, 3389-3395. https://doi.org/10.1128/AEM.02240-08

[20] Moqsud, M., Yoshitake, A.J., Bushra, Q.S., Hyodo, M., Omine, K. and Strik, D. (2015) Compost in Plant Microbial Fuel Cell for Bioelectricity Generation. Waste Management, 36, 63-69.

[21] Wang, X., Feng, Y., Wang, H., Qu, Y., Yu, Y., Ren, N., Li, N., Wang, E., Lee, H. and Logan, B.E. (2009) Bioaugmentation for Electricity Generation from Corn Stover Biomass using Microbial Fuel Cells. Environmental Science and Technology, 43, 6088-6093. https://doi.org/10.1021/es900391b

[22] Hassan, S.H.A., Gad El-Rab, S.M.F., Rahimnejad, M., Ghasemi, M., Jin, H.J., Yong, S.O., In, S., Kim and Sang, E.O. (2014) Electricity Generation from Rice Straw using a Microbial Fuel Cell. International Journal of Hydrogen Energy, 39, 9490-9496.

[23] Velasquez-Orta, S.B., Curtis, T.P. and Logan, B.E. (2009) Energy from Algae using Microbial Fuel Cells. Biotechnology and Bioengineering, 103, 1068-1076. https://doi.org/10.1002/bit.22346

[24] Jauharah, M.K., Boris, T. and Raghavan, G.S.V. (2015) Effect of C/N Ratio and Salinity on Power Generation in Compost Microbial Fuel Cells. Waste Management, 48, 135-142.

[25] Brahmaiah, P., Subba, R.C., Jerald, A.L. and Daniel, D.H. (2016) Optimizing the Performance of Microbial Fuel Cells Fed a Combination of Different Synthetic Organic Fractions in Municipal Solid Waste. Waste Management, 49, 73-82.

[26] Resch, G., Haas, R. and Faber, T. (2008) The Future Potential for Renewable Energies Assessment of Their Realisable Mid-Term Potential up to 2020 at Global Scale. Final Report of a Study on Behalf of International Energy Agency, Renewable Policy Unit. Energy Economics Group at Vienna University of Technology, Vienna.

[27] Li, J. (2013) An Experimental Study of Microbial Fuel Cells for Electricity Generating: Performance Characterization and Capacity Improvement. Journal of Sustainable Bioenergy Systems, 3, 171-178. https://doi.org/10.4236/jsbs.2013.33024

[28] Walter, E. and Dean, J.R. (1974) Determination of Carbonate and Organic Matter in Calcareous Sediments and Sedimentary Rocks by Loss on Ignition: Comparison with Other Methods. Journal of Sedimentary Petrology, 44, 242-248.

[29] Quanguo, Z., Jianjun, H. and Du, J.L. (2016) Microbial Fuel Cells as Pollutant Treatment Units: Research Updates. Bioresource Technology, 217, 121-128.

[30] Fedorovich, V., Knighton, M.C., Pagaling, E., Ward, F.B., Free, A. and Goryanin, I. (2009) Novel Electrochemically Active Bacterium Phylogenetically Related to Arcobacter Butzleri, Isolated from a Microbial Fuel Cell. Applied and Environmental Microbiology, 4, 7326-7334. https://doi.org/10.1128/AEM.01345-09

[31] Juang, D.F., Yang, P.C., Chou, H.Y. and Chiu, L.J. (2011) Effects of Microbial Species, Organic Loading and Substrate Degradation Rate on the Power Generation Capability of Microbial Fuel Cells. Biotechnology Letters, 4, 2147-2160. https://doi.org/10.1007/s10529-011-0690-9

[32] Logan, B.E. and Regan, J.M. (2006) Electricity-Producing Bacterial Communities in Microbial Fuel Cells. Trends in Microbiology, 14, 512-518. 
[33] Moqsud, M.A., Bushra, Q.S. and Rahman, M.H. (2011) Composting Barrel for Sustainable Organic Waste Management in Bangladesh. Waste Management \& Research, 29, 1286-1293. https://doi.org/10.1177/0734242X10383621

[34] Moqsud, M.A., Omine, K., Yasufuku, N., Quazi, S.B., Hyodo, M. and Nakata, Y. (2014) Bioelectricity from Kitchen and Bamboo Waste in Microbial Fuel Cell. Waste Management \& Research, 32, 124-130. https://doi.org/10.1177/0734242X13517160

[35] Jati, S.H. (2001) Pemanfataan Kompos Daun Jati dan Mikrohiza untuk Pembibitan Jati. [Utilization of Teak Leaf Compost and Mycorrhiza for Teak Nursery.] Institut Pertanian Bogor, 7.

[36] Hamzah, Z. (1983) Diktat Ilmu Tanah. Pusat Pendidikan Kehutanan Cepu, Direksi PerumPerhutani. [Soil Science Textbook. Cepu Forest Education Center.] 